\title{
Ranch Business Planning and Resource Monitoring for Rangeland Sustainability
}

\author{
By Kristie A. Maczko, John A. Tanaka, Michael Smith, Cindy Garretson-Weibel, \\ Stanley F. Hamilton, John E. Mitchell, Gene Fults, Charles Stanley, Dick Loper, \\ Larry D. Bryant, and J. K. "Rooter" Brite, Jr.
}

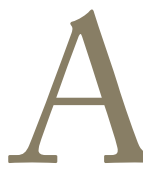

ligning a rancher's business plan goals with the capability of the ranch's rangeland resources improves the viability and sustainability of family ranches. Strategically monitoring the condition of soil, water, vegetation, wildlife, livestock production, and economics helps inform business plan goals. Business planning and resource monitoring help keep ranchers on the land, support the well-being of rangeland-dependent communities, and conserve the rural way of life. To work toward this goal, the Sustainable Rangelands Roundtable (SRR)i, Wyoming Business Council (WBC), Wyoming State Grazing Board (WSGB), University of Wyoming Extension, Grazing Lands Conservation Initiative (GLCI), Samuel Roberts Noble Foundation, USDA Forest Service Rocky Mountain Research Station, Natural Resources Conservation Service, and several ranchers formed the SRR Ranch Sustainability Assessment Group. The working group focuses on implementing a monitoring framework for ecological, economic, and social sustainability within the context of ranchers' business plans.

Ranchers, and the rangelands they manage, provide commodity, amenity, and spiritual values ${ }^{1}$ that are vital to the well-being of ranchers, the communities in which they live, and the nation as a whole. These goods and services include forage for grazing animals, wildlife habitat, water storage and filtration, carbon sequestration, recreation opportunities, and a way of life for rangeland-dependent communities. ${ }^{2}$ As society strives to satisfy multiple demands with increasingly finite resources, availability of quantifiable information as a basis for rancher decision making becomes more important.

Ranchers regularly adapt their business practices to changing markets, regulatory requirements, and demands for various goods and services. Collecting monitoring data

'For more information on the Sustainable Rangelands Roundtable, visit http://www.sustainablerangelands.org. to track trends in the elements of their individual business plan goals is critical to the long-term sustainability of ranch operations. For instance, grazing land use for wildlife habitat, as well as wildlife-related human activities, is projected to increase during the next half century. ${ }^{3}$ Managing ranches for wildlife resources is likely to become a more viable business option in the future. Tracking trends in supply and demand of livestock and wildlife forage and associated products can help ranchers effectively allocate their efforts and investments in feed, equipment, labor, and land.

Managing for multiple goals beyond cattle production can benefit ranchers and communities by increasing income and conservation goals. For example, Arizona's Malpai Borderlands Group has developed a grass bank that offers ranchers an opportunity to rest grazed areas without selling cattle or land. This reserve improves rangeland condition, promotes wildlife habitat, and mitigates land development pressures. Similarly, The Nature Conservancy's Red Canyon Ranch has seen both a $50 \%$ increase in calf production and an improvement in rangeland condition, demonstrating that ecologically sound management can be economically profitable. ${ }^{4}$

Some evidence shows that profitable cattle ranching operations can enhance conservation by keeping ranches intact, preventing subdivision development and protecting biodiversity. ${ }^{4}$ By increasing wildlife abundance and diversity, or maintaining habitat for rare plants, ranchers may be able to diversify their income and net worth. Bird watchers, amateur botanists, and nature enthusiasts may pay to visit their ranches and search out these entities for recreation..$^{5-7}$ Land managers and other stakeholders realize that livestock grazing does not have to negatively affect the richness of rangeland birds or lead to the loss of rare plants..$^{8-10}$

Rangeland Sustainability-People and Process To more specifically address sustainability at the ranch level, participants of the SRR Ranch Sustainability Assessment 
Group convened to identify indicators best suited for monitoring ecological, economic, and social conditions on the individual ranch operation level to complement business planning goals. This effort builds upon existing SRR products, as well as programs administered by the NRCS, the Noble Foundation and the WBC, to sustain western rural landscapes, lifestyles, and livelihoods.

Criteria are statements of categorical conditions or processes that are goals of sustainable development. Indicators are natural and social variables that may be monitored, providing quantitative measures of trends in human wellbeing and economic and natural resource conditions. ${ }^{11} \mathrm{SRR}$ participants have identified rangeland monitoring indicators for five criteria: 1) conservation and maintenance of soil and water resources on rangelands, 2) conservation and maintenance of plant and animal resources on rangelands, 3) maintenance of productive capacity on rangelands, 4) maintenance and enhancement of multiple economic and social benefits to current and future generations, and 5) legal, institutional, and economic frameworks for rangeland conservation and management. The regional and national SRR criteria and indicators appear in full detail as the core of SRR's First Approximation Report on Criteria and Indicators for Sustainable Rangelands. In this article we focus on a subset of these indicators that can be modified for use in ranch-level monitoring and business planning. The complete SRR Sustainable Ranch Management Assessment Guidebook is available electronically and downloadable at no charge, along with several presentations designed to provide additional information. .i $^{\text {pre }}$

\section{SRR Ranch Assessment Indicators}

The online SRR Sustainable Ranch Management Assessment Guidebook ${ }^{i i i}$ takes ranchers through a self-assessment questionnaire to evaluate the current sustainability of their operation. That information helps ranchers identify areas where they may want to improve, including conducting ranch resource monitoring in conjunction with developing a formal business plan to guide progress toward common operational goals.

With consideration for the quantity and quality of data that a rancher would have time and interest in collecting and evaluating, the SRR working group adapted 17 indicators (Table 1) from the 64 national and regional indicators originally identified by SRR.

The Ranch Assessment indicators recommended were selected with three key characteristics in mind: 1) the measure for an indicator is quantifiable; 2) the indicator

\footnotetext{
iiThe SRR Sustainable Ranch Management Assessment Guidebook can be downloaded at no charge from http://sustainablerangelands.org/ ranchassessment

iii The SRR Sustainable Ranch Management Assessment Guidebook is available at http://sustainablerangelands.org/ranchassessment/pdf/ ranch_guidebook_B1216.pdf.
}

should inform the business plan to allow ranchers to track progress toward their individual ranch goals and objectives; and 3) the indicator is monitored at the ranch scale and measurable by ranchers and/or technical service providers. We also assessed monitoring techniques for each indicator, in terms of methods, time commitment, available technical assistance, and skill level required.

Indicators should be interpreted in the context of movement towards a management goal specified in a rancher's business plan. Monitoring should provide the data that the ranch business tracks to see if its goals are being achieved. The SRR Sustainable Ranch Management Assessment Guidebook includes an appendix with more detailed information about suitable data collection methods for monitoring the following indicators.

\section{Soil Indicators}

Bare ground. This indicator measures the percent of bare ground as an indicator of the potential for erosion by raindrop impact and wind. Bare ground is commonly estimated from linear transects using point-intercept sampling techniques.

\section{Table 1. SRR ranch assessment indicators}

Soil indicators

Soil stability

Bare ground

Water indicators

Water volume

Availability of surface water

Plant indicators

Species composition of plant communities

Fire

Invasive species

Riparian areas

Animal indicator

Wildlife populations

Productive capacity indicators

Forage utilization

Harvestable material production

Domestic meat produced

Socioeconomic indicators

Profit from livestock production and each product produced

Visitor use information for recreational enterprises

Legal and institutional indicators

Continuing education and technical assistance

Protection of special values

Weather-related indicators

Weather conditions 
An example of this monitoring technique is presented in more detail in the Wyoming Rangeland Monitoring Guide. $^{12}$

Soil aggregate stability. Soil aggregate stability is an indirect indicator of erosion potential. This indicator measures the degree to which soil aggregates (clumps) retain their structural integrity when exposed to a water bath. For additional information on this protocol, see Version 4 of the Interpreting Rangeland Health Manual. ${ }^{13}$

\section{Water Indicators}

Two indicators were selected to address water volume and the duration of water availability in a stream, spring, or reservoir. Access to and quantity of water for livestock and other animals, as well as aquatic habitat values, can be important assets. Ephemeral water sources may limit the suitability of some areas for livestock grazing and wildlife habitat. Vegetation management has been shown to impact stream and spring flows. Clearly, climatic conditions and prevailing weather patterns have a profound influence on water availability and abundance.

Volume of water available. This indicator measures the quantities of water available across a pasture or operation and relates it to existing or projected needs, including water needs for animal consumption and maintaining aquatic and riparian resources over time.

Frequency or duration of surface water. This indicator addresses the season and length of time that reliable quantities of water are available on a ranch, and how that timing relates to a ranch's capacity to support desired uses. If the availability of ephemeral water begins to decrease on an annual basis, management responses or changes to business plan goals may be necessary. Timing of water resources is a

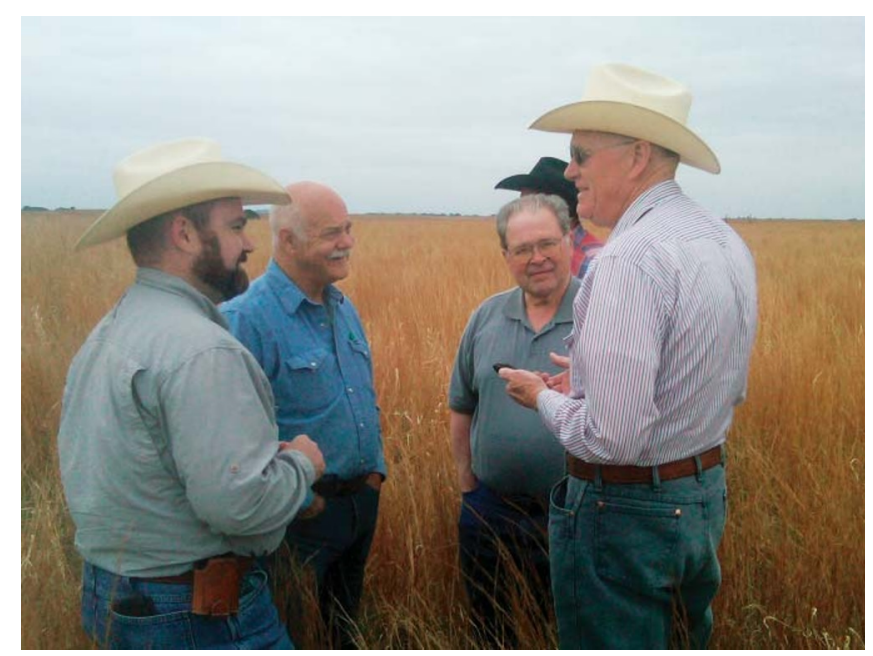

Rancher J. K. "Rooter" Brite, Jr., confers with Stan Hamilton, John Mitchell, and Chad Ellis (NRCS) about selection of monitoring sites for vegetation and soil on his JA Ranch near Bowie, TX. The JA Ranch was a 2010 regional Environmental Stewardship Award winner and is one of several operations implementing the monitoring and business planning process for rangeland sustainability. companion indicator with the volume of water available and the two should be evaluated together.

\section{Plant Indicators}

Key species composition. Changes in the abundance of key species in the plant community provide the rancher with an indication of the efficacy of a land management program in maintaining or moving toward the desired plant composition. This indicator measures the abundance and distribution of key plant species-those that provide significant benefits in terms of forage, habitat, site stability, or intrinsic values. In some cases, key plant species are sensitive to different land and livestock management strategies. Data collection for this indicator involves measuring point data on permanent line transects in critical areas. Note that the same transect used to assess bare ground can be used for this indicator. More specific information on this monitoring protocol is available in the Wyoming Rangeland Monitoring Guide. ${ }^{12}$

Extent of invasive species. This indicator focuses upon tracking the presence, distribution, and abundance of invasive plant species. Extent and abundance of invasive species may be recorded with the same point sampling procedure as used for monitoring key species. However, presence of newly established invasive plants must be determined from some other manner, such as periodic inventories, visual reconnaissance from horseback, and continual vigilance by ranch owners, employees, and visitors.

Extent of wildfire and prescribed fire (by year). In systems where wildfire is prevalent and/or prescribed burning is practiced, maintaining a map of fire locations, dates of fires, and burn frequency data for individual sites can serve several purposes. This information provides indications of fire suppression needs, fuels management opportunities, and vegetation treatment priorities. Soil cover and vegetation cover/composition monitoring in burn areas may be desirable, along with tracking weather conditions (temperature, humidity, precipitation, etc.) during burning season.

Extent and condition of riparian areas. This indicator describes the location, extent, and health of riparian areas on the ranch. The greenline technique ${ }^{14}$ provides a percent cover by plant community type along streams. Additional information is available in the Wyoming Rangeland Monitoring Guide. ${ }^{12}$

\section{Animal Indicators}

Animals on a ranch include marketable commodities, such as livestock and game animals, as well as pests such as feral hogs or predators. Other species may be of special value solely for their presence. Depending on the species, objectives may be to increase populations, to maintain stable numbers, or to manage for decreases in populations. Wild ungulates and feral hogs can have a significant influence on ranch management. These animals also may offer potential for ranch commodity use and an additional source of income.

Population estimates of wildlife (or feral) species. This indicator estimates trends in population levels (abundance) of key 
wildlife species (upland game birds, song birds, large ungulates, game fish). Population estimates are collected with the objective of characterizing general trends in animal numbers and distribution. Monitored species will be those of interest to the rancher as part of a ranch enterprise-or for reasons of personal interest. General trends in population levels may be obtained through systematic annual counts done at the same time of day, at the same time each year, on the same route, with the same weather conditions..$^{15}$ If wildlife-related enterprises such as bird watching or trophy hunting are major areas of emphasis for an operation, the rancher may opt to employ additional survey methods including track, fecal, nest, or den counts, trap and release, or call and response. Additional data may be obtained from state departments of wildlife and/or the US Fish and Wildlife Service.

\section{Productive Capacity Indicators}

Productive capacity indicators are likely to be a key consideration in designing a monitoring program and crafting business plan goals, since these elements may be closely tied to economic return. Aspects to consider include forage utilization, pounds of meat produced, and comparable measures of other products produced for sale.

Forage utilization. This indicator measures annual forage use levels or residual forage in pastures on the ranch. In the short term, utilization of forages (i.e., use levels, stubble height, or residual forage across the landscape in key areas) represents the general adequacy of management of animal numbers, distribution of grazing, provision of forage for alternative species, and soil surface protection. Values will be impacted by slope, water, and presence of shrubs. Possible techniques to estimate forage utilization include the Livestock Utilization Landscape Appearance Method, ${ }^{12}$

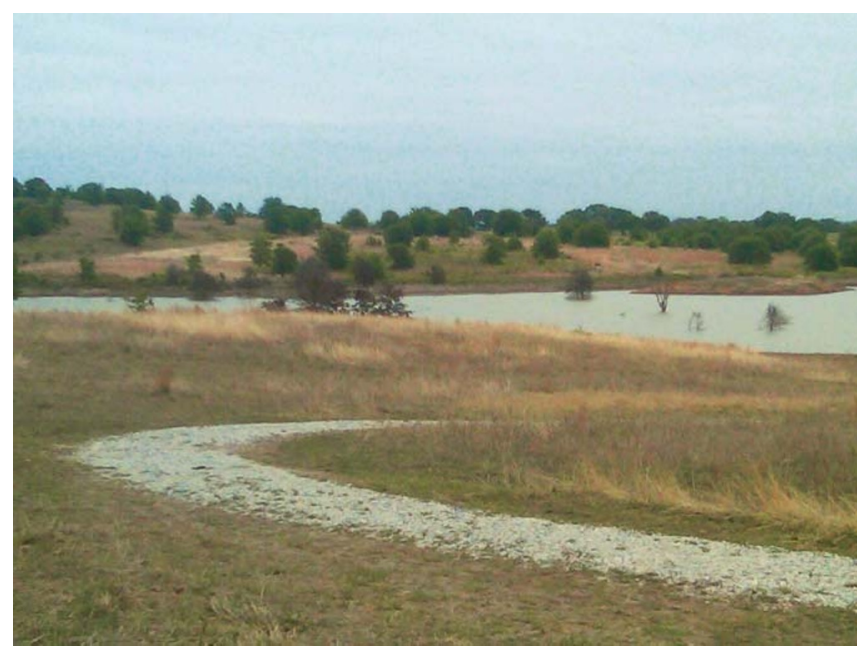

Using lakes, ponds, and tanks, rancher J. K. "Rooter" Brite, Jr., ensures water availability for his livestock and wildlife operations on the JA Ranch near Bowie, TX. Water availability is one of the 17 ranch sustainability monitoring indicators recommended by the Sustainable Rangelands Roundtable. stubble height measured along line transects, and/or paired plot sampling with grazed areas and grazing exclosures.

Livestock products. This indicator measures the outputs of ranch enterprises that produce meat and other products from beef cattle, sheep, bison, elk, emus, and/or goats, and other grazing animals raised for commercial purposes.

Nonlivestock harvestable products. This indicator measures the output of non-livestock products that are produced on the ranch, including hay, seeds, nuts, wood, and other plant materials. Alternative profit centers may be of particular value when viewed in the context (i.e., as a percentage) of all sources of income for a ranch operation.

\section{Socioeconomic Indicators}

These indicators are designed to capture the economic elements of a ranching operation, as well as the social factors that may impact the operation's sustainability; income and expenses predominate.

Cost of livestock production. This indicator measures the production costs of the products produced on the ranch such as the cost of purchased and raised feed for livestockgenerally one of the largest expenses for ranchers. All costs, including opportunity costs (replacement costs or what you would have to pay for your next best alternative), should be determined and documented. Direct and indirect (overhead) costs should be calculated.

Itemized incomelexpense of each product produced. This indicator measures the cost per unit of production, a very effective interpretive tool, which can then be used to generate a break-even price. The cost per unit of production can be subtracted from the return per unit to calculate the net return to the operator. All enterprises (livestock, forage, hay, labor, hunting, bird watching, rock hounds, facilities, etc.) should receive a separate analysis. The percentage of the operation's net return from each enterprise may be useful in allocating time and other resources to various profit centers.

Visitor use information for appropriate enterprises. This indicator measures the number of visitor use days associated with enterprises that allow people to visit a ranch for a price based on a particular activity such as hunting, bird-watching, rock collecting, etc. It is useful to document the number of visitors and the fees they pay to access the ranch, in order to calculate and document dollars per visitor and the number of visitor days on an annual or seasonal basis. In addition, cost trends can be useful in determining efficacy of nonconsumptive land use enterprises.

\section{Legal and Institutional Indicators}

The legal and institutional indicators are generally less quantifiable than others in the monitoring framework, although they are equally important in the context of a rancher's business plan.

Continuing education and technical assistance. This indicator measures the use of technical assistance and continuing 
education (Cooperative Extension Service, GLCI, NRCS programs, land trusts, etc.) by members of the ranch family and management team. Ranchers can track their participation, and that of their family and employees, in these activities using a catalog detailing the type of training or assistance sought, duration, and skills obtained. How frequently a rancher seeks technical assistance and continuing education may be an indicator of a mind-set that fosters ongoing assessment and improvement in an operation. A thorough approach includes setting educational and training goals, scheduling periodic assessment of goals, and then setting new educational and training goals.

Protection of special values. This indicator helps identify and monitor special values that may be noneconomic or perhaps even costly to maintain. This could include an inventory listing of historical sites such as cabins, old wagon trails, fire lookouts, cultural areas like old cemeteries or Native American ceremonial sites, and others of significance to the family. The inventory would include type, condition, and location of such sites. Once the sites and their values are identified and inventoried, goals are established and documented to deal with these special values. Periodic review of the goals, as well as an assessment of the results of management activities is recommended.

\section{Weather-Related Indicators}

These elements are general purpose measures that ranchers should monitor because of the profound effects weather related phenomena can have on a ranching business.

- Temperature-This measures the temperature range at selected points on a ranch on a daily basis over the entire year.

- Precipitation-This measures rainfall and snowfall amounts at selected sites on a ranch on a daily basis over the entire year. Drought conditions on a ranch can be identified using information obtained from data collected, assessed, and presented in useable form by government agencies and other sources.

Ranchers may want to correlate temperature, precipitation, and drought condition reports with other events and conditions on the ranch. Ecological, social, and economic monitoring data in combination with weather records can assist a rancher in better balancing ranch resource capabilities with family ranch business plan goals and objectives. Monitoring data and business plans are both useful management tools individually, but combining the two optimizes sustainable ranch management and rangeland sustainability.

\section{Ranch Business Planning}

A business plan builds upon resource information gathered through a ranch monitoring plan, based upon the idea that ecologically sound management is also economically profitable and socially acceptable management, i.e., sustainable ranch management. The SRR Sustainable Ranch Management
Assessment Guidebook summarizes business planning and succession planning information. Additional resources are also available through services offered by organizations like the Wyoming Business Council.

Ranchers and farmers are continually challenged to remain economically sustainable, especially with the marginal profitability of traditional commodities. Having a framework to assess the business component of a ranching operation is critical to enhance profitability and/or reduce expenditures.

A rancher's business plan documents operational, financial, and personal objectives. It contains detailed steps and budgets to identify how these objectives can be reached. The business planning approach works best with technical advice and assistance from professional advisors such as bankers, extension agents and educators, land management agency resource managers, other successful ranchers, and community specialists.

\section{Business Plan Components}

Whether a rancher seeks to diversify his/her operation or adjust current management (like transitioning to retaining yearlings from a cow/calf operation), a business plan guides the decision-making process. Specifically, a comprehensive business plan contains the following: ${ }^{16}$

- Executive summary-A one or two page overview of the plan, highlighting important points.

- Overview of the industry and business-Information about the overall ranching operation, current industry status and trends, potential new markets, a description of the ranching operation, and how it fits into the industry overall. Where should the business focus its market activities (local, regional, national, or international markets)? The mechanics and required resources are fundamentally different at each level and costs vary widely.

- Market analysis-Presents opportunities to pursue. Components include products or services provided, features and benefits, a customer analysis, analysis of the competition, competitive advantage of a ranching operation, market size and trends, and market potential.

- Market plan-The overall marketing strategy for the ranch, whether selling beef to a feedlot or a hunting experience to a client. Components include the product (what will be sold), the placement or distribution (how does the product get to the customer), the price, and promotion.

- Management team-Detailed resumes of key persons in the ranch business, as well as external resources such as the accountant, attorney, and key advisors. For producers using federal or state grazing lands, it may include a range conservationist or other agency personnel.

- Financial plan-Represents the best estimate of future operations for financial stability. This includes profit and loss projections, cash flow projections, and pro-forma balance sheets. 
- Break-even analysis-The point at which the total costs equal the total income, i.e., where net income or profit begins. Once the business plan is developed, proposed management changes or new enterprises can be plugged into the business plan to evaluate their potential impact on the operation's profitability.

- Appendix-This section should include any supporting documents associated with the plan: maps, job descriptions, pictures and drawings, resource inventories, infrastructure (buildings, fences, equipment, water supplies, etc.) inventories, etc.

\section{The Business Planning Process}

Identifying values, goals, knowledge, skills, interests, and abilities of all family members and key employees on the ranch is an important first step in developing the business plan. Figure 1 shows how the business plan development process works. ${ }^{16}$ A key component is a feedback loop activated whenever some factor of the business changes. The business planning process includes the following:

- Exploring personal and family values

- Developing personal, family, and operational goals

- Evaluating personal business skills and traits for each family member including their lifestyle and financial management expertise

- Evaluating personal natural resources and local community resources and knowledge and

- Completing an inventory of all resources associated with the ranch.

Personal values are one's standards and convictions. Examining family values involves communicating each family member's personal values and then comparing them. Shared values offer a focal point for setting goals, which in turn provide a framework for decision making. Once identified, goals should be written down. They should be specific, measurable, attainable, and relevant and have a deadline for accomplishment.

It is significant to note that maximizing profit is not necessarily the key consideration for being a sustainable ranching operation. Perhaps, having all family members work on the ranch or the way of life is more important than increasing profit.

Assessing individual skills, traits and abilities is equally important to identifying values when developing a business plan. The workbook Sustaining Western Rural Landscapes, Lifestyles, and Livelihoods ${ }^{16}$ provides a guide to the overall assessment process for business planning and highlights the following:

- Personal traits and characteristics assessment-Traits (attitudes, habits, motivation) and skills relevant to running a business

- Lifestyle and family traits assessment-Level of family unity and strength, including current or potential conflicts
- Family financial management assessment-Basic financial practices and financial plans

- Business skills and traits assessment-Individual strengths and weaknesses of family members necessary to the business

- Natural resources awareness assessment-Role of natural resources in the current operation and consideration of which natural resources may provide additional income

- Community resources awareness assessment-Community resources available and your involvement and participation in the community.

Compiling this information feeds into development of an overall analysis of the Strengths, $W$ eaknesses, Opportunities, and Threats (a "SWOT" analysis) for the ranching operation. Private landowners, as well as those with leased or permitted lands, will find a completed business plan a valuable tool in making management decisions.

\section{Conclusions}

The Sustainable Rangelands Roundtable and related efforts invite innovation and experimentation with ecological, economic, and social ranch sustainability assessment. Federal land management agency leadership has pledged to broaden and deepen a commitment to sustainability as they recognize that helping ranchers stay on the land enhances their internal efforts to preserve open space and maintain buffers between developed areas and federal protected lands. Opportunities to develop partnerships, expand information exchange, and employ integrated monitoring and business planning for improved rangelands assessment will increase with sustainable resource management implementation.

The SRR Ranch Sustainability Assessment Group and their partners will continue to improve this process, building upon existing frameworks by incorporating feedback from stakeholder workshops held at the Society for Range Management and Soil and Water Conservation Society annual meetings with support from the Western Sustainable Agriculture Research and Education program. ${ }^{\text {iv }}$ This workgroup looks forward to engaging all interested partners in monitoring and reporting upon SRR indicators for ranch sustainability assessment to fulfill SRR's mission to "promote social, ecological, and economic sustainability of rangelands through the development and widespread use of criteria and indicators for rangeland assessments," and to provide "a forum for dialogue on sustainability of rangelands." Ultimately, comprehensive, comparable information will inform discussion and debate about economic, social, and ecological rangeland sustainability issues to improve rangeland management and profitability, as well as public visibility and understanding of rangeland management issues.

iv Workshop presentation files are available at http://sustainablerangelands. org/ranchassessment. 


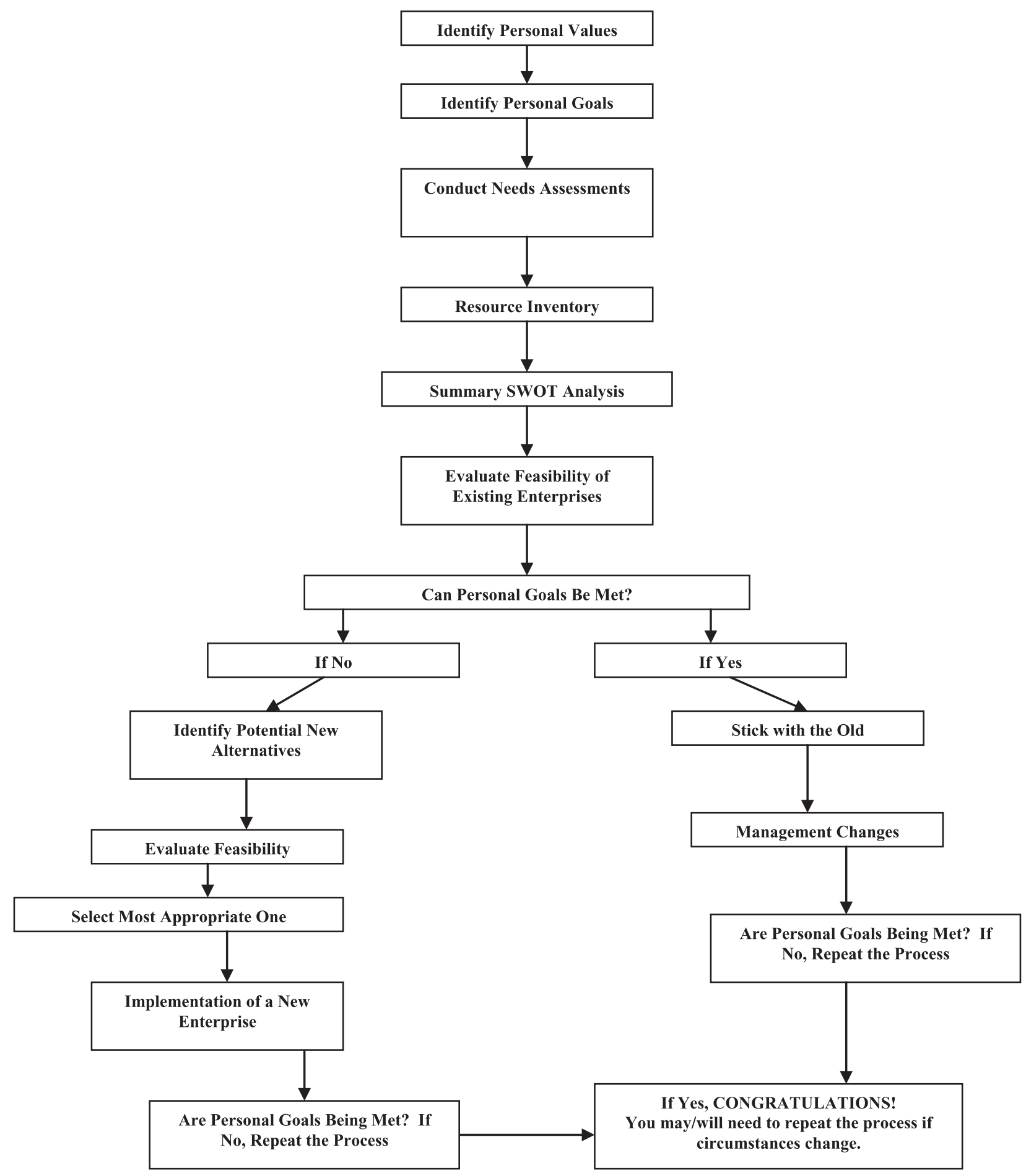

Figure 1. Business planning process flow chart.

\section{References}

1. Shields, D. J., I. M. Martin, W. E. Martin, and M. A. Haefele. 2002. Survey results of the American public's values, objectives, beliefs, and attitudes regarding forests and grasslands. Fort Collins, CO, USA: USDA Forest Service Rocky Mountain Research Station. General Technical Report RMRS-GTR-95. 111 p.
2. Maczko, K. A., And L. A. Hidinger [eds.]. 2008. Sustainable rangelands ecosystem goods and services. Fort Collins, CO, USA: Colorado State University, Warner College of Natural Resources. SRR Monograph No. 3. Sustainable Rangelands Roundtable. $111 \mathrm{p}$.

3. Van Tassell, L. W., E. T. Bartlett, and J. E. Mitchell. 2001. Projected use of grazed forages in the United States: 2000 
to 2050: a technical document supporting the 2000 USDA Forest Service RPA Assessment. Fort Collins, CO, USA: USDA Forest Service Rocky Mountain Research Station. General Technical Report RMRS-GTR-82. 73 p.

4. Jensen, M. N. 2001. Can cows and conservation mix? Bioscience 51:85-90.

5. Butler, L. D. 1990. Nontraditional uses of rangelands for income producing activities. In: Proc. Income Opportunities for the Private Landowner through Management of Natural Resources and Recreational Access, 9-12 April 1989. Wheeling, WV, USA. RD No. 740. p. 122-127.

6. Berger, M. E. 1973. Recreation potential of Texas Rangelands. Journal of Range Management 26(2):92-93.

7. Rowan, R. C., and J. P. Workman. 1992. Factors affecting Utah ranch prices. Journal of Range Management 45(3):263-266.

8. Kantrud, H. A. 1981. Grazing intensity effects on the breeding avifauna of North Dakota native grasslands. Canadian Field-Naturalist 95:404-417.

9. Kantrud, H. A., and R. L. Kologiski. 1983. Avian associations of the northern Great Plains grasslands. Journal of Biogeography 10:331-350.

10. McClaran, M. P., and P. C. Sundt. 1992. Population dynamics of the rare orchid, Spiranthes delitescens. Southwestern Naturalist 37:299-333.

11. National Research Council Board on Sustainable Development. 1999. Our common journey: a transition toward sustainability. Washington, DC, USA: National Academy Press. 384 p.

12. Wyoming Range Service Team. 2001. Wyoming rangeland monitoring guide: a cooperative and voluntary approach to monitoring rangelands. Cheyenne, WY, USA: Wyoming Department of Agriculture. $34 \mathrm{p}$.

13. Pellant, M., P. Shaver, D. A. Pyke, and J. E. Herrick. 2005. Interpreting indicators of rangelands health, version 4. Denver, CO, USA: United States Department of the Interior. Bureau of Land Management Technical Reference 1734-6. $136 \mathrm{p}$.

14. Winward, D., D. Zamudio, and K. Zamudio. 2000. Monitoring the vegetation resources in riparian areas. Ogden, UT, USA: USDA Forest Service, Rocky Mountain Research Station. General Technical Reference RMRS-GTR-47. 55 p.
15. Braun, C. E. [ED.]. 2005. Techniques for wildlife investigations and management. 6th ed. Bethesda, MD, USA: Wildlife Society. 974 p.

16. Wyoming Business Council. 2003. Sustaining western rural landscapes, lifestyles and livelihoods through agricultural enterprise diversification: a collaborative approach. Cheyenne, WY, USA: Wyoming Business Council. 385 p.

Authors are Research Scientist, Dept of Renewable Resources, University of Wyoming, and Deputy Director, Sustainable Rangelands Roundtable, 2150 A Centre Ave, Suite 361, Fort Collins, CO 80526, USA, kmaczko@uwyo.edu (Maczko); Department Head, Dept of Renewable Resources, University of Wyoming, and Director, Sustainable Rangelands Roundtable, 1000 E University Ave, Laramie, WY 82071, USA (Tanaka); Professor, Dept of Renewable Resources, University of Wyoming, Laramie, WY 82071, USA (Smith); Agribusiness Director, Wyoming Business Council, 214 W 15th St, Cheyenne, WY 82002, USA (Garretson-Weibel); Director, retired, Idaho Dept of Lands, 11148 Seneca Dr, Boise, ID 83709, USA (Hamilton); Rangeland Scientist Emeritus, USDA Forest Service Rocky Mountain Research Station, 2150A Centre Ave, Suite 361, Fort Collins, CO 80526, USA (Mitchell); GLCI Rangeland Management Specialist, NRCS-West National Technology Support Center, 1201 NE Lloyd Blvd, Suite 1000, Portland, OR 97232-1201, USA (Fults); GLCI Rangeland Management Specialist, NRCS-Central National Technology Support Center, 501 W Felix St, Bldg 23, Fort Worth, TX 76115, USA (Stanley); Rangeland Management Consultant, Wyoming State Grazing Board, PO Box 1202, Lander, WY 82520, USA (Loper); Rangeland Management Consultant and Rancher, Bryant Ranches EF Consulting, PO Box 4B, Long Creek, OR 97856, USA (Bryant); and Treasurer and Rancher, Grazing Lands Conservation Initiative National Steering Committee and JA Ranch, PO Box 1477, Bowie, TX 76230, USA (Brite). Funding and support for this project come from the Western Sustainable Agriculture Research and Education program, the Bureau of Land Management, the Natural Resources Conservation Service, and the USDA Forest Service. 